\title{
A STATISTICAL OBSERVATION OF THE RELATION BETWEEN PALATINE TONSILLAR LESIONS AND DENTAL DISEASE
}

By

\author{
Y. UCHIDA AND S. UNNO
}

\author{
From the Department of Oto-Rhino-Laryngology, Tokyo Medical Callege \\ (Director: Prof. T. Shiroizea)
}

There has been no discussion about the relation between palatine tonsillar lesions and decayed teeth. Nine hundred and sixty-three cases were examined and relation between tonsillar lesions such as inflammatory or physiological hypertrophy, and dental lesions such as decayed teeth or gingivitis were studied. The patients selected were between 12 and 14 years of age. Conclusions were as follows:

1. There was close relationship between inflammatory hypertrophy of the palatine tonsils and apicitis of the teeth and gingivitis.

2. There was no relation between the side of tonsillar lesion and that of detal lesion.

3. There was relation between the severity of the dental lesions and tonsillar lesions in order of grade I, grade II hypertrophy after Mackenzie and burried type lesion.

4. Since the disease is on the border line of the two fields of medicine, further studies by the otorhinolaryngologists and dentists should be made.

\section{口蓋扁桃の病変と齟㐘との関連に就いての統計的観察}

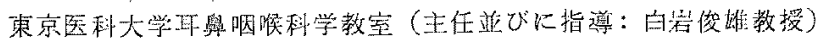

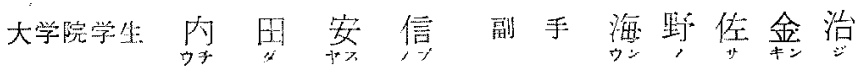

\section{目次}

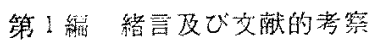

第 1 落楮言

籍 2 音 交献的考察

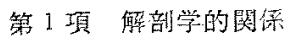

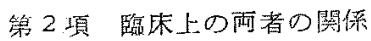

筑了項 形態及び生理的前びに病的变化

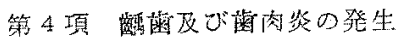

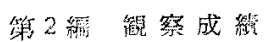

第 1 项 定例の䌊括

符 2 填 部查要項

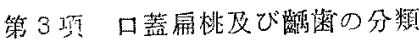

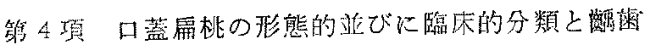
之o関䌽

第 3 粨 考按立びに結馀 文献

\section{第 I編 緒言及び文献的考察}

第 1 算: 緒

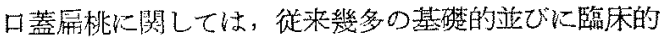
研究業續が举げら机ているが，生理的には先の機能が末

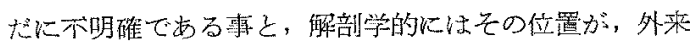

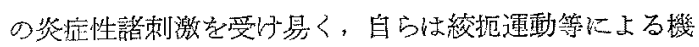

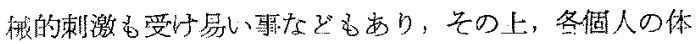

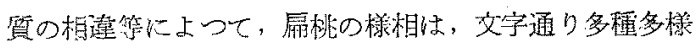

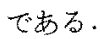

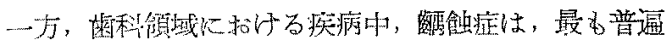

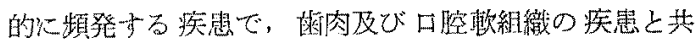

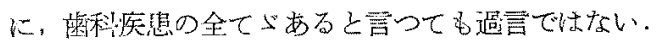

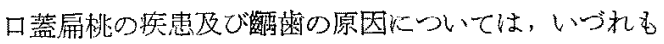

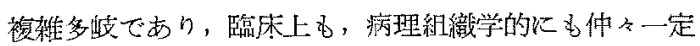

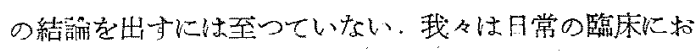

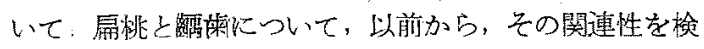


討していたが，两者とも去の解剖学的位置が，外来の炎

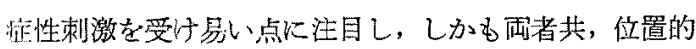
には，至近の巨離にあり，各酯の条件にむ似かよつてい

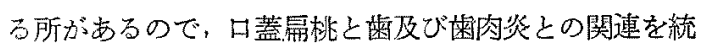
訓的に見る事を企図した。

先ず, 口蓋扁桃の臨床的症状を心とし，これ《附随

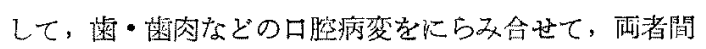

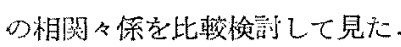

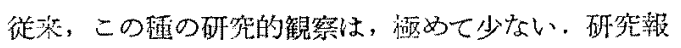

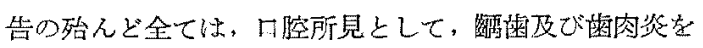
直接刘称にしていない，問題にされているのは，患者の

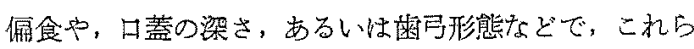
を、間接的に口蓋扁桃の病变と比較検話しているもの みである。

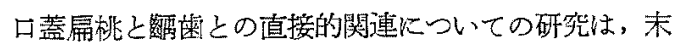
だ見られないよらである、従つて，その大凡を識るため には，多くの症例につき個く精查し，関連があると思 わ机る点を，逐次取り挙げ犯ばならない，それ等の綜合

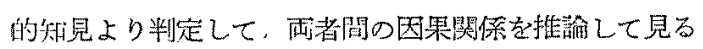
辌上する。そしてこれ等の知見が多少なりとも，耳鼻科 医及び歯科医の日常の臨床に，参考々なつて，役立つ事 があれば韾である。

\section{第 2 章 文献的考察}

口蓋扁桃については, 従来幾多の研究業精があるの

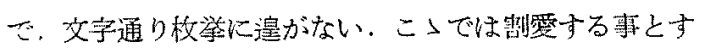
3 .

\section{第! 項}

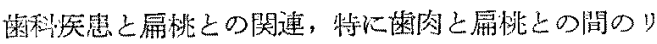
ン八路についでは, Cruick-schank (1789) の研究があ

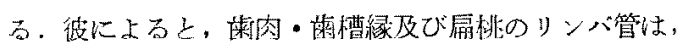
外頸動脈汇沿つて走り，下顎緑を越えてからは，外頸静

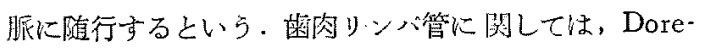
ndorf (1910), Most (1906) 等によつて研究され, Schweitzer (1907) 《至つて，その研究は泀よ゙完成の

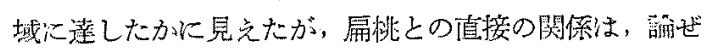
られていない，1914年に Henke によって，初るて実

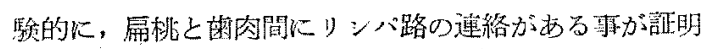

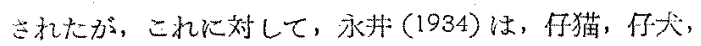
家雨などを用いて実験した結果，庿肉之扁桃の間にリン

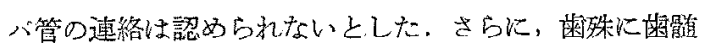
のリンパ路に関しては, Magnus (1907), 西塚 (1932) 等によつて研究が行なおれたが，その結果，それぞれの 所属シンパ節との関係が解明されたのみで，米と扁桃と
のリンパの関係については言及されてい就い.1934 年 に至り，羽田野は，雨及び口蓋扁桃間のリンパ路の連絡

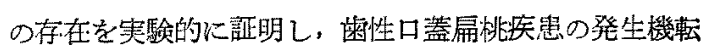
に一根拠を与克るに至つた。

\section{第 2 項 臨末上の恶者の関係}

1934 年の日本医学会総会で，耳舅科之䨑科の共同宿

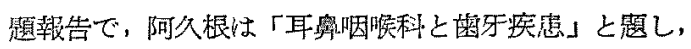

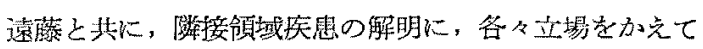
研究した成果発表している。その中で，口蓋扁挑之掬

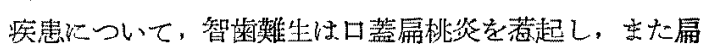
桃周四炎を起乙易い事をのべ，を大逆儿，扇桃周四膿瘍

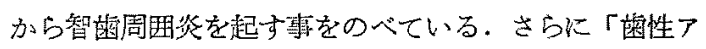
ンギーナ」の定義亚びにその成因について簡略にのべて いる.

1954 年山崎は，栄蚨学的見地から，常食之扁桃肥大， 風邪, 鼠・咽頭炎, 幽露及び年令などとの関保を統計的 に钼察し，偏食者（肉食過剩青菜不足食）には，扁桃肥 大溍やアンギナ等を有するるのが多いと指摘している.

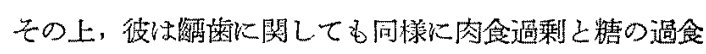
とをとり挙げ，食品の美，不味に拘わらず，去の抒媒は 個人の体質に基づくもので，好食品が現在の体質を持続 するものとした。しかし，禹物質の過食はこの領域にお いても各種の化膿症（広義）以罪患する傾向を增加する と結んでいる、また，伊落，堀内，极村等はアデ，イト

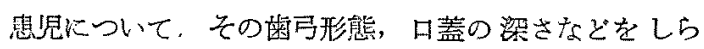

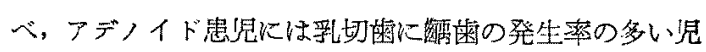
童が非常に多数いる可をのべている，その他雨矣患と直

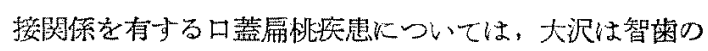
根端性荬朕炎から同時に同側扁桃に肥大, 発赤及び神経 痛梯疼痛を起した症例をあげ，患速の病原菌市るいは瑇 菜等の刺激炕よて，扁桃が肥大し，あるい恃その他の 病変を起したすのであるうと述べている。伊欢は上顠の

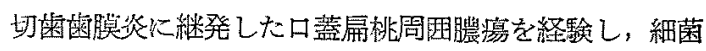

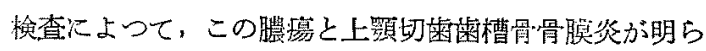
かに一方が原因であり，他方が結果であつたとのべてい

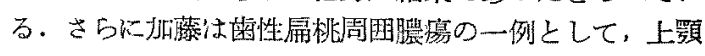
臼幽の拔去に因るるのがあつた牙寒を説明している。磨

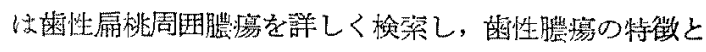
して，扁桃自身は通常殆んど正常であるのに，その遥か

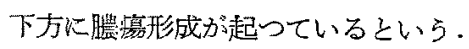

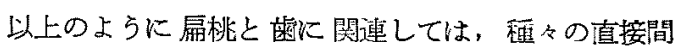
接の関係が研究されているが, 雨者の解剖学的位置, 細 菌学的環境, 時間的関係等を教滤すると, 日常の臨床に 
招いてもな绝々な新しい関連事項が見出されるのでは ないかと想像される。

\section{第 3 項 口蓋屚桃の形態及び生理的並びそ病的} 変化

口蓋扁桃は小巟期において最大の発䏍を示し，14〜15

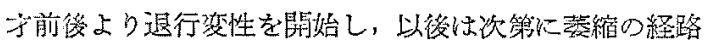
を辿つていく事は，内外交献上よりる明らか旅来篹であ る。すなわち, Fox (1886), Hett (1910), Butterfield

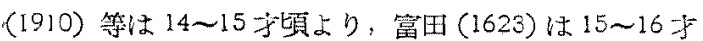
上り, Hellmann (1929) は5 6 チでも既に退化を示 少例もあると記載しているまた，犻態的には，Mackenzie は前後口蓋弓の平面上り哭出したものを肥大泟 として，第I度，第【度，第目度に分類したが，实地臨 床上で法今な招この方法が相当利用されている，Grad-

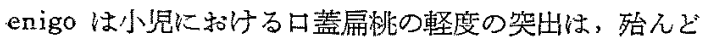
総て生理的のものであるとし、神尾, 高橋, 細谷, 山 本, Levinstein 等は口盍扁桃の 単純性肥大と罹患に上 る病的肥大との鑑別は困難であるとしている，笹木は口 蓋扁桃の生理的機能として杼々な身体防禦説を述べてい る. 玉た最近, 白岩は口蓋扁桃の発育は生後 1 年後より 解次增大し，4〜5于より7〜8于前後に执いて最大とな り，14〜15 术以後になって，免疫状態や，摃取食物に 対する注意力等が確保されるに至れば，淄㳄退化傾向を 示して縮小すると述心゙，さらに電要な事惊，雪の慢性疾 患がしばしば慢性咽頭炎知に限局性の炎症の原因になつ ており，それが見逃されている事が多い之述べ，注目さ れている。

外見上の形鄁のみから扁桃の肥大を区別すると，機能 的肥大と病的肥大とになり，この区別は甚だ困難であ る. 皆藤は種々の敩点加ら両者を比較研究し，その綃

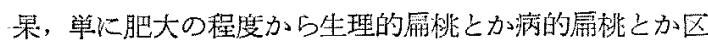

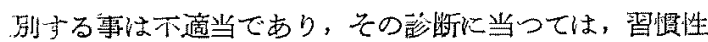
䍜虫度が重要な急義を有する事を認好ている。面に実地 臨床上でも生理的扇桃之病的扇桃の間には，習慣性䍜患 度数, 㕣患時の庭状, 㐼発症, 家流歴, 扁桃表面の状 態，腺窝や上窝の所見，前口蓋弓等に確実な差異を認め たと強調している。

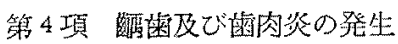

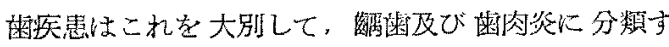
る㐨ができるが，艺の成因に䦛しては，W.D. Miller （1890）の化学細菌説をはじ好諸説があって，多岐多椂

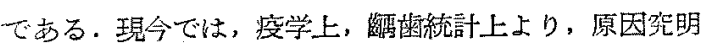
のために新たな研究が続々発表されて一応一般的な要因

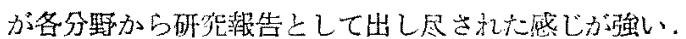

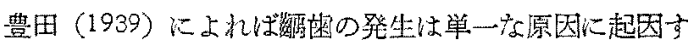
るものではなく，原因的要案の存在のもとに，周所的条 件的要菜が具倩する承により，発生するものであるとい

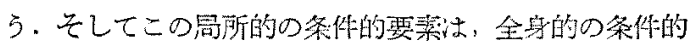
要素によつて文右されるものであると述べている。その

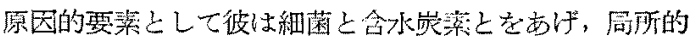

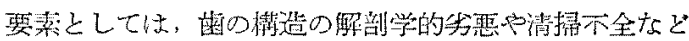

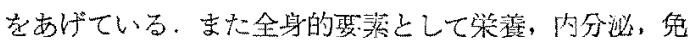
没，全身病などとの関係に竍及している。また米沢 （1939）は口腔細菌学の立場加ら，歯及び屜桃の慢性炎 症は第 1 次感染原栄として，病栄感染上電要であり，第 2 次感染原栄 (リンハ節)を介して発生した全射疾腎の 治撩には, 第 1 次感染原巣の処理のため, 耳舅科々橉科 之の隣接领域疾患として，两稕の医師の協力が是非共要 望されると強調している，1957年の学校得生統計報告

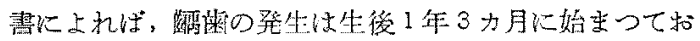

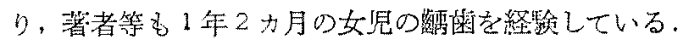

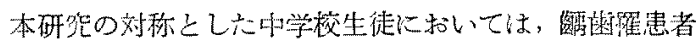
の率は 12 才で50.0\%，13才゙台で $46.3 \%$ ，14 才台で50.1

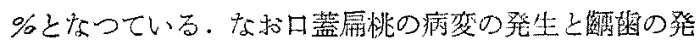
生とは，報告㻎の上ては丁度時機加一致てている事も判

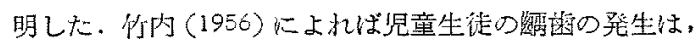
戦時（昭和16 年)上り戦後になつて急速低下し, 昭和 24 26 年が最子低く，昭和 27 年より再び刍カーブで上

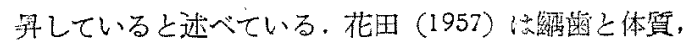

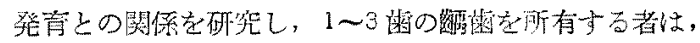

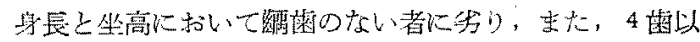

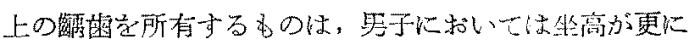

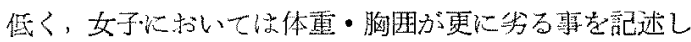
ている。

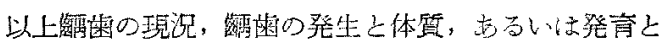

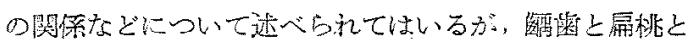
の関遗を直接的に取扱かつた研究は，未た見ない。

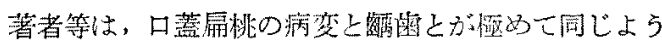
な時期と采件で登生している点, さらに屚桃の生理的萎

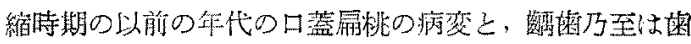

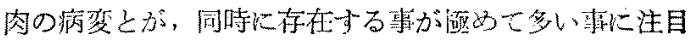
し，この研汽の端緒とした次第である。

\section{第 2 編 観 察成 縝}

、第1 章 聇例の総括

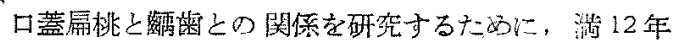

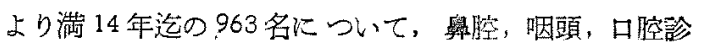




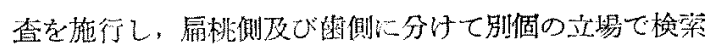
した。丁应この年命の生㹤を迩しだ㻎由は，文献上上

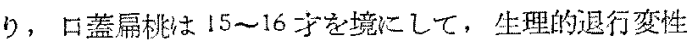
が始まり，父のたかに覧床上の肉腿的所是にこれらの変

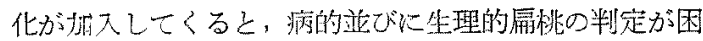

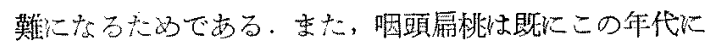

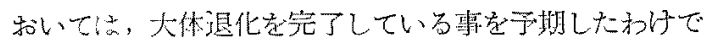
ある。

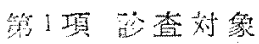

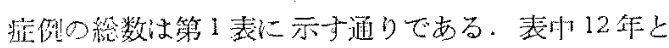

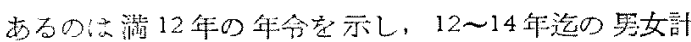

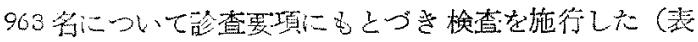
1).

\begin{tabular}{|c|c|c|c|}
\hline \multirow{2}{*}{\multicolumn{2}{|c|}{ 第 1 表 }} & \multicolumn{2}{|c|}{ 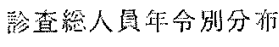 } \\
\hline & & 男 & 㰠 \\
\hline 12 & 年 & 125 & 109 \\
\hline 13 & 年 & 175 & 149 \\
\hline 14 & 年 & 207 & 198 \\
\hline & 計 & & \\
\hline
\end{tabular}

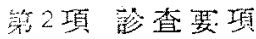

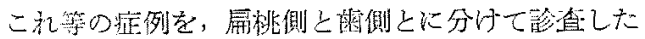

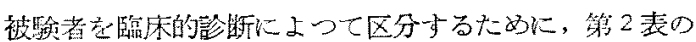

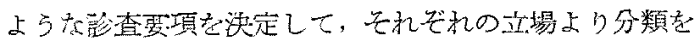

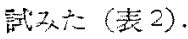

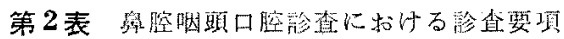

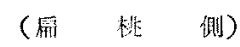

1. 肥大勘

埋谈 犁

第 I 度

第 II度

第 吕 度

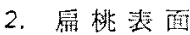

腺窋の非列

膿检, 上窜

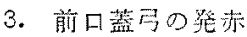

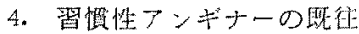

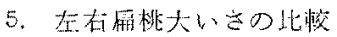

6. Zの他の偣症

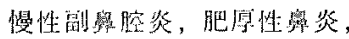
腺粎增雅症，紫资等
(阐)
例)

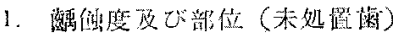
$\mathrm{C}_{1}, \mathrm{C}_{2}, \mathrm{C}_{3}$

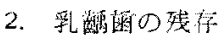

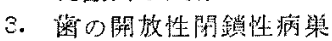

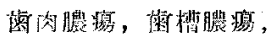

\author{
慢性根端病栄 \\ 畒就の存在

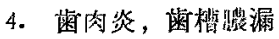 \\ 菌石，因班沈着 \\ 5. 不正咬合 \\ 蒾の位置買常 \\ 丵弓形態 \\ 6. 萠出中の永久画

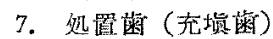

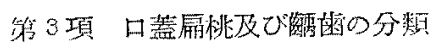

口盖尉桃は形態的に肉眼的分類を Mackenzie の分類

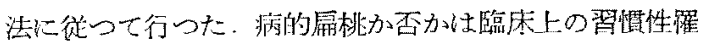

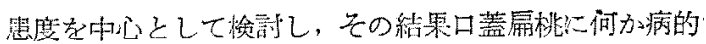

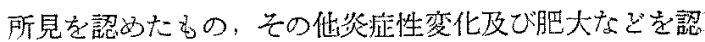
められた者を含めると963名の中から319名が抽出され， た、その成績は第了表に示した通りである（表了）。

第3表 口蓋雨桃に所見を認めたもの

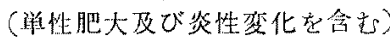

\begin{tabular}{|c|c|c|c|}
\hline & & 罗 & 奴 \\
\hline 12 & 袢 & $41(33 \%)$ & $33(3396)$ \\
\hline 13 & 年 & $51(29 \%)$ & $44(30,6)$ \\
\hline 14 & 年 & $83(40 \%)$ & $67(32 \%)$ \\
\hline & & \multicolumn{2}{|c|}{319 名 $(33 \%)$} \\
\hline
\end{tabular}

第 4 表 口篮扇桃の形態的分類

\begin{tabular}{|c|c|c|c|c|}
\hline & & \multirow{2}{*}{ 年 令 } & 例 & 数 \\
\hline & & & 罗 & $k$ \\
\hline \multirow{3}{*}{ 理 } & \multirow{3}{*}{ 係 剡 } & 12 㲛 & 5 & 9 \\
\hline & & 13 年 & 14 & 5 \\
\hline & & 14 种 & 18 & 11 \\
\hline \multirow{2}{*}{ 第 } & 慢 & 12 年 & $3 \mathrm{~L}$ & 15 \\
\hline & & 13 作 & 20 & 15 \\
\hline 把 & 大 & 14 年 & 37 & 19 \\
\hline \multirow{2}{*}{ 第 } & \multirow{3}{*}{$\begin{array}{l}\text { 瘦 } \\
\text { 大 }\end{array}$} & 12 年 & 3 & 8 \\
\hline & & 13 年 & 16 & $2 j$ \\
\hline & & 14 尔 & 25 & 34 \\
\hline \multirow{5}{*}{$\begin{array}{l}\text { 第 } \\
\text { 把 }\end{array}$} & \multirow{3}{*}{ III 蓝 } & 12 f & 2 & 1 \\
\hline & & 13 年 & 1 & 3 \\
\hline & & 14 行 & 3 & 3 \\
\hline & & . & 175 & 144 \\
\hline & & 尌 & 31 & \\
\hline
\end{tabular}

な求，これらの症例を形態的に下記の规集に徒つて分 けて芫ると第 4 表の結果となる。 
1）埋没型 前後口蓋弓私面上り内方

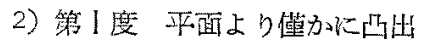

3）第 II度 口蓋垂との中間の線迄

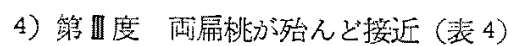

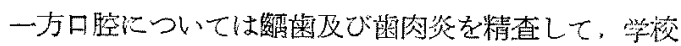
画科衛生の分類法に従つて

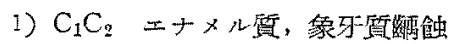

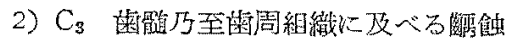
とに区分した（表5).

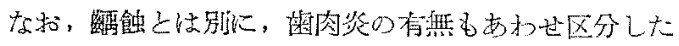
(表6).

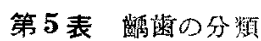

\begin{tabular}{|c|c|c|c|c|c|c|c|}
\hline & & \multicolumn{3}{|c|}{ 男 } & \multicolumn{3}{|c|}{ 女 } \\
\hline 年 令 & 臽展 & $\mathrm{C}_{3}$ & $\mathrm{C}_{1} \mathrm{C}_{2}$ & 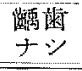 & $\mathrm{C}_{3}$ & $\mathrm{C}_{1} \mathrm{C}_{2}$ & 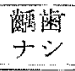 \\
\hline 12 & 篚 & 114 & 49 & 16 & 41 & 41 & 17 \\
\hline 13 & 年 & 61 & 85 & 29 & 47 & 85 & 17 \\
\hline 14 & 狳 & 47 & 119 & 39 & 77 & 103 & 37 \\
\hline
\end{tabular}

第 6 表 画肉次の分頪

\begin{tabular}{|c|c|c|c|c|c|}
\hline & & \multicolumn{2}{|c|}{ 劦 } & \multicolumn{2}{|c|}{ 左 } \\
\hline 年 命 & 炎定の有無 & $\begin{array}{c}\text { 蔽肉炎 } \\
(+)\end{array}$ & $(-)$ & $\begin{array}{c}\text { 圈讪炎 } \\
(+)\end{array}$ & $(-)$ \\
\hline 12 & 梠 & 21 & 104 & 27 & 82 \\
\hline 13 & 年 & 29 & 146 & 19 & 130 \\
\hline 14 & 律 & 50 & 157 & 42 & 156 \\
\hline
\end{tabular}

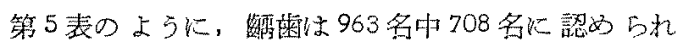
た。ただしこの場合1 日滾を1単位として計上し， $\mathrm{C}_{3}$ 洁 $\mathrm{C}_{1}, \mathrm{C}_{2}$ に供先して採算した。第6表の上5に， 料肉状は963名中 188 名に見られた (19.5\%).

以上のよ5に分類された凮者について，扁桃の形態

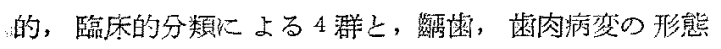
的，臨床的分類炕上る 3 群上を，备年命別，至女別に分 けてその所見を比蔽検討し，さらに病变の見られない群 同志について子此輘檢討して見た。

第 4 項 口盖扇桃の形態的並び䧗床的分類之

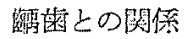

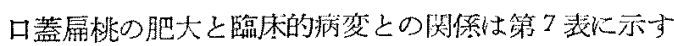
通りである。各年令別に整理して見ると，口蓋屚挑で 第 I 度肥大, 第 II 度肥大, 埋没型の順に数が多いものか ら少いものに分つ事ができた。とこらが期せずして，C

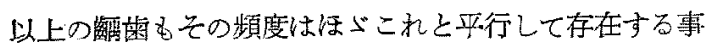

が判明した。

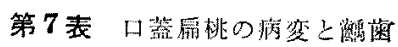
$\left(\mathrm{C}_{s}\right.$ 以上) と阴係

\begin{tabular}{|c|c|c|c|c|c|c|}
\hline & \multicolumn{3}{|c|}{93} & \multicolumn{3}{|c|}{ th } \\
\hline & 两 桃 & 栺西 & 菌 & 熶 桃 & 䚘的 & 莼 \\
\hline \multirow{3}{*}{12} & 埋没型 & 5 & 2 & 埋没型 & 9 & 3 \\
\hline & 第 I度 & 31 & 20 & 第 1 度 & 15 & 11 \\
\hline & 籍 II 废 & 3 & 2 & 第 II 度 & 8 & 3 \\
\hline & 第四度 & 2 & 2 & 筙顾度 & 1 & 1 \\
\hline \multirow{4}{*}{13} & 埋没型 & 14 & 8 & 埋治型 & 5 & 3 \\
\hline & 第 ] 度 & 20 & 6 & 第 1 度 & 15 & 6 \\
\hline & 笰 III 糜 & 16 & 9 & 第 【度 & 21 & 15 \\
\hline & 第 III 度 & 1 & I & 第政度 & 3 & 3 \\
\hline \multirow{4}{*}{14 年 } & 埋没瑟 & 18 & 7 & 埋沟型 & 11 & 7 \\
\hline & 埒 I 度 & 37 & 12 & 第１度 & 19 & II \\
\hline & 篦 II 璴 & 25 & 11 & 策 II 隻 & 34 & 16 \\
\hline & 筆四废 & 3 & 2 & 第政管 & 3 & 1 \\
\hline
\end{tabular}

全体在通して53060万恕

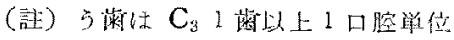

すな方ち例を12年の嘼生徒にとると，第I度肥大 31 に

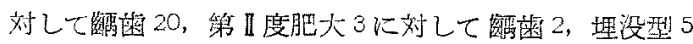

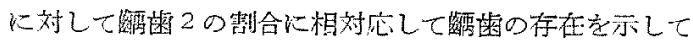

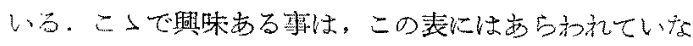

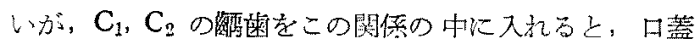
唡桃に何等か心病的所見があるものには，同一人に同洔

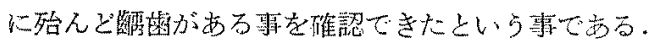

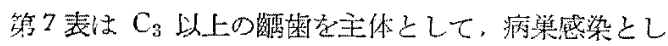
ての䈍義を考慮に入れたものでこの上らな見方でこの

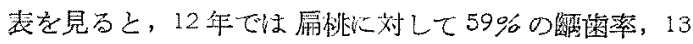

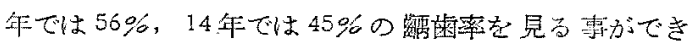

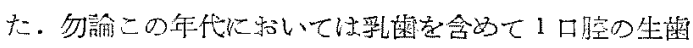

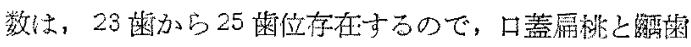

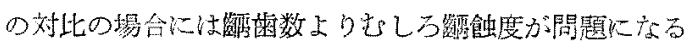

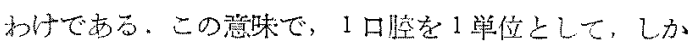
\& $\mathrm{C}_{3} 1$ 涵以上の存在を基準として計数したのでする.

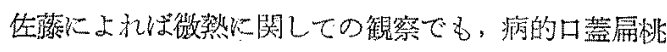
と同じ頻度に整の疾患が存在するという。このような意 味から我ふの成㺓を全部総括した場合，病的口蓋扁桃所

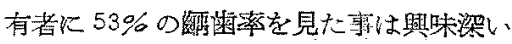

逆に，敂䨑を全く有しない口腔がでの程度に病的口盖 扁桃を有寸るかを見るべきであつて，この事は聯述の第 
19 表を参照されたい。

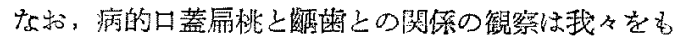

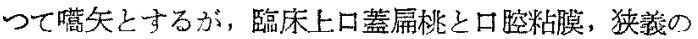
米肉との関連は, 明確な記戴こそないが関璉のある事は 認められている。

こっで我々も国肉炎を例にとつて,この関係を比輘检

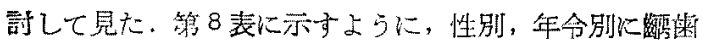

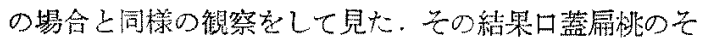

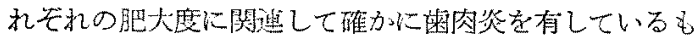
のが多い、しか子，この表に表現されていないが，同一

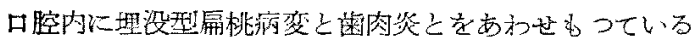
といら症例が甚だ多い歌柱目に值する。。

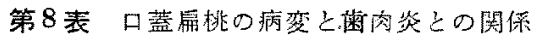

\begin{tabular}{|c|c|c|c|c|c|c|}
\hline & & 男 & & & 女 & \\
\hline & 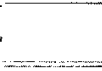 & $\begin{array}{l}\text { 䌟桃 } \\
\text { 病变 }\end{array}$ & 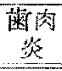 & & $\begin{array}{l}\text { 㻞桃 } \\
\text { 病齐 }\end{array}$ & $\begin{array}{c}\text { 落吻 } \\
\text { 炎 }\end{array}$ \\
\hline & 埋设型 & 5 & 3 & 埋咲型 & 9 & 7 \\
\hline 12 企: & 第 1 策 & 31 & 10 & 第 | 应: & 15 & 9 \\
\hline & 篚 II 应 & 3 & 1 & 篌 $\|$ 度 & 8 & 5 \\
\hline & 第西度 & 2 & 0 & 第项活: & 1 & 1 \\
\hline & 埋涴型 & 14 & 7 & 埋沒型 & 5 & 2 \\
\hline 13 尔 & 第了度 & 20 & 8 & 第 | 篖 & 15 & 4 \\
\hline & 第 【度 & 16 & 7 & 第 \|应 & 21 & 8 \\
\hline & 策传度 & 1 & 0 & 第四度 & 3 & 1 \\
\hline & 理淡型 & 18 & 14 & 埋济㤠 & 11 & 5 \\
\hline 14 应 & 第 1 度 & 37 & 15 & 第 I 宸 & 19 & 5 \\
\hline & 第严 & 25 & 12 & 第 II 度 & 34 & 22 \\
\hline & 籍 步 宸 & 3 & 1 & 第相度 & 3 & 1 \\
\hline
\end{tabular}

全体を通じて47％。菌肉炎艼

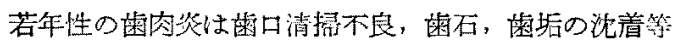
によつて起名ものとされているか゚，我々の例においてま これらの原因以外の特殊の原因があるとは考无られなか。

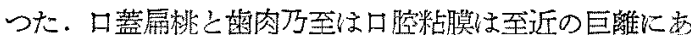

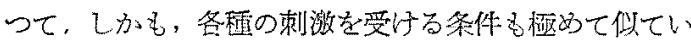

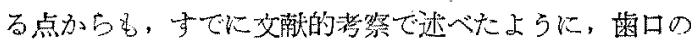
清掃不全，生活環境，その他扇桃囷牙環境带のいかんに

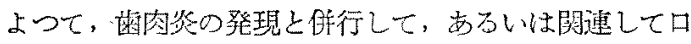

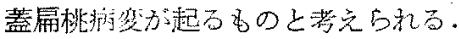

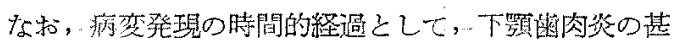

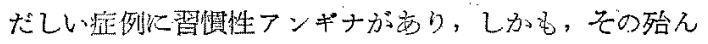

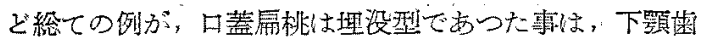

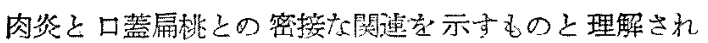

3 .

羽田野によつて明らかたされた所の，口蓋扁桃之因肉

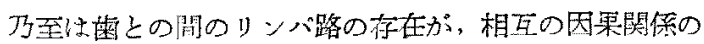
成立の上に与つて力あるものである事は蒜ら余地がな w.

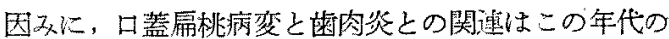

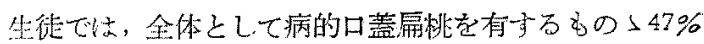

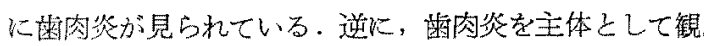

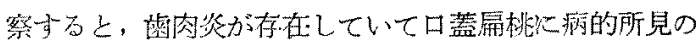

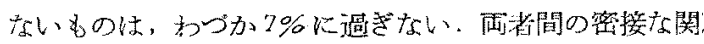

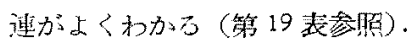

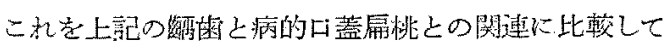

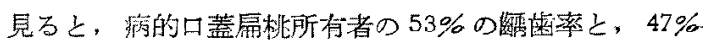
の粜肉炎察となり，数字の上では武肉炎の率の方方低

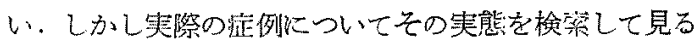

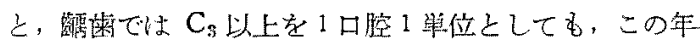

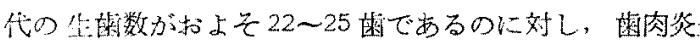

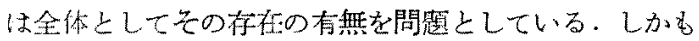

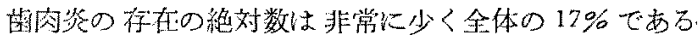
とい5事も一応考慮する必要がある。

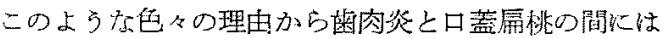

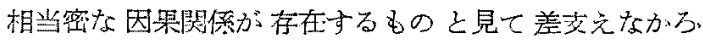
5 .

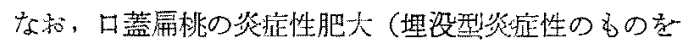

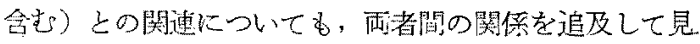

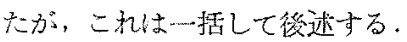

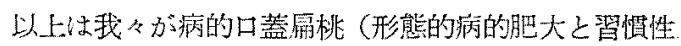

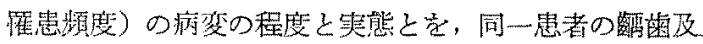

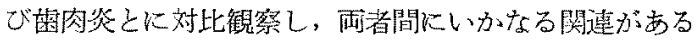
ふを检討した成績である。

さて，一方我ふはさらに, 前述の疮的口蓋扁桃を実地 臨床上篗 9 表に示したような指䅺に基つ゚いて，生理的肥

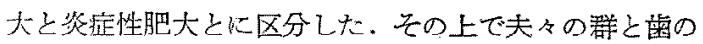
疾患上の閶連がどの上うになつているがついても研究

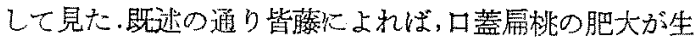

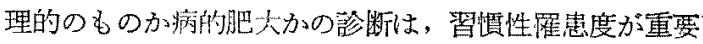

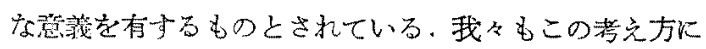
筫成する者で，従つて被検者の習慣性渥患度を判定基淮 の中心として肥大日蓋聂桃を分類した所，第10表の上 らな成縝が出た。これで見ると备学年の思女別に梌㚗成

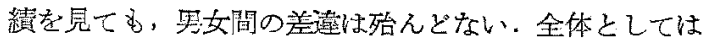
生理的肥大 85 名に対して炎症性肥大 234 名を数える事 か゚できた。すなかる生理的肥大の約 3 倍の割合に炎泟性 
肥大が存する事が判明し，これは白岩の記裁と全く一致 している。

第9表 口盖扁桃に站ける生理的肥大と 炎症性肥大との比较対照

(生理的肥大)

1. 㥜慣性ない，あってもご怪度

2. 推患時定状ない, あっても発熱程度

3. 例発症少い

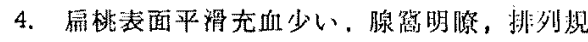
則性，膿恮少い。上篦不明，㳀い

5. 前口蓋弓充血少い，䠌転性良好 (炎症性肥大)

1。習慳性有り中高度

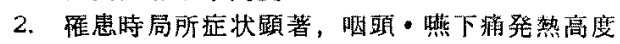

3. 牦発症アレルギー急慢性腎㷋

4. 表面凹凸不平，充血多乙，腺窝不明嘹，排列 不规則，膿栓多く上望明膫澡い

5. 前口蓋弓充血著明, 舀転性不良

第 10 表 口蓋扁桃に括ける生理的肥大・ 炎症性肥大の比較

\begin{tabular}{|c|c|c|c|c|c|}
\hline 性 別 & \multicolumn{2}{|c|}{ 男 } & \multicolumn{3}{|c|}{ 女 } \\
\hline 年令扁桃 & 生 - 肥 & 焱 - 肥 & 生 - 肥 & 炎 & - 把 \\
\hline 12 年 & 11 & 30 & 9 & & 24 \\
\hline 13 年 & 16 & 35 & 13 & & 31 \\
\hline 14 年 & 22 & 61 & 14 & & 53 \\
\hline
\end{tabular}

生理的肥大：炎症性肥大 $=85: 234$

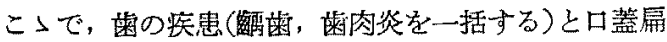
桃の炎拉性肥大との閔連を検案して見た，その結果は第 11 表に示す上らに，男・女，年令間の差湋は殆んどな く，12年のもので $97 \% ， 13$ 年で $97 \% ， 14$ 年で $90 \%$ の 剨合で，炎症性口蓋扁桃肥大のある者の殆えど総てに，

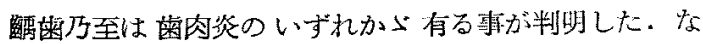
拉，この表で年令 14 年の者に若干の一致率の低下を見

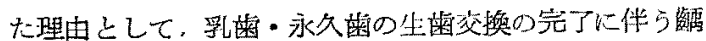

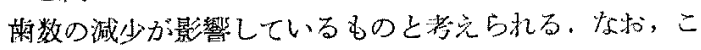
の倹查に当つては，前述の如く，不正答合及び萠出中の

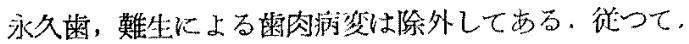

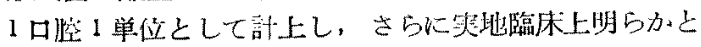

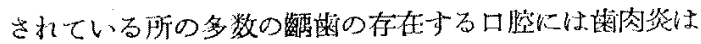

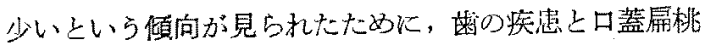
炎症性肥大との関連は殆えぞ 100\%に近い一致率を見た るのと解される。

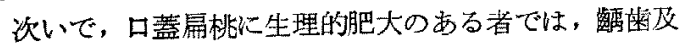
び四肉炎とどのような関你があるかを梌慗して見た。す

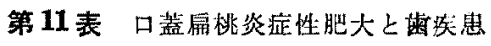

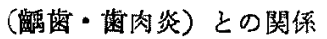

\begin{tabular}{|c|c|c|c|c|}
\hline 䅘 別 & \multicolumn{2}{|c|}{ 男 } & \multicolumn{2}{|c|}{ 女 } \\
\hline 年命病变 & 炎 - 肥屏桃 & 歯 疾 患 & 炎 - 肥扁桃 & 苜䛈 唯 \\
\hline 12 筷 & 30 & 29 & 24 & 23 \\
\hline 13 年 & 35 & 34 & 31 & 30 \\
\hline 14 年 & 61 & 53 & 53 & 49 \\
\hline \multicolumn{5}{|c|}{12 年では $97 \%$} \\
\hline \multicolumn{5}{|c|}{13 年 $\quad 97 \%$} \\
\hline \multicolumn{5}{|c|}{14 年 $\quad 90 \%$} \\
\hline
\end{tabular}

全体として94.5\%の一致染

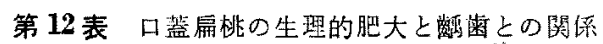

\begin{tabular}{|c|c|c|c|c|c|}
\hline 传: 别 & \multicolumn{2}{|c|}{ 男 } & \multicolumn{3}{|c|}{ 女 } \\
\hline 等会病贸 & 生 - 肥 & 触踽 & 生 - 肥 & 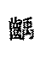 & 蒾 \\
\hline 12 年 & 11 & 6 & 9 & & 8 \\
\hline 13 企 & 16 & 5 & 13 & & 3 \\
\hline 14 年 & 22 & 4 & 14 & & 4 \\
\hline
\end{tabular}

生理的肥大：唃菡 $=85: 30(35.3 \%)$

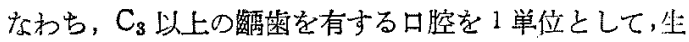
理的肥大のある 口蓋扁桃との関連を検案すると，第 12 表のようになる。蓋扁桃の生理的肥大者 85 名に対し

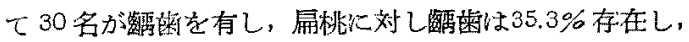

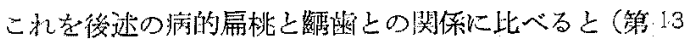

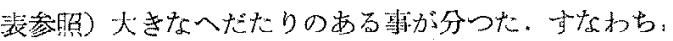

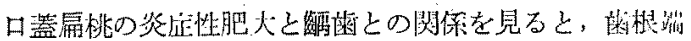

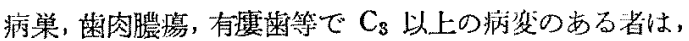
口蓋㧂桃の炎怔性肥大者の 234 名に刘して135名に义儿 でいる。すなわち，炎症性肥大者の57\%に相当して斯

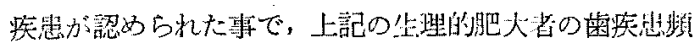
度上り遥加多い䧼を物語つている。

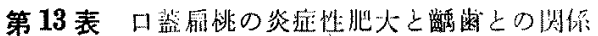

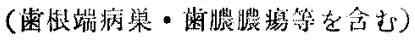

\begin{tabular}{|c|c|c|c|c|c|c|}
\hline 性 别 & \multicolumn{2}{|c|}{9} & \multicolumn{4}{|c|}{ 女 } \\
\hline $\mathrm{S}_{1} \mathrm{C}_{1}$ & 炎 - 脏 & 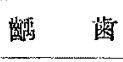 & 炎 & - 继 & 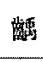 & 菻 \\
\hline 12 年 & 30 & 20 & & 24 & & \\
\hline 13 年 & 35 & 19 & & 31 & & \\
\hline 14 垂 & 61 & 28 & & 53 & & \\
\hline
\end{tabular}

炎症性肥大：被菌=234：135(57\%) 
結局, 炎定性口蓋扁桃肥大は，生理的肥大に比較し

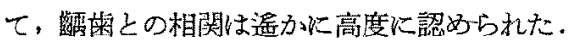

次に, 霜肉の病变について子, 生理的口蓋扁桃鿱大と 炎注性肥大とに分けて，之の各々汇対する関連の程度を 比較険討して見た，先す，生理的肥大と菌肉炎とについ て，黑女，年令別に炎の関椎をしらべて見ると，第 14 表の上らに，85名の生理的肥大に対して，矢の $25 \%$ に 当る 22 名の者に茵肉炎が見られた。所が，炎怔性肥大 者234名に対しては，126名，与なわち，54\%の老に雨 肉焱が認奶られた（第15 表).

第 14 表 口盐扁桃の生理的肥大之栶肉炎との関倸

\begin{tabular}{|c|c|c|c|c|}
\hline 性 别 & \multicolumn{2}{|c|}{ 男 } & \multicolumn{2}{|c|}{ 女 } \\
\hline 年令病変 & 生 - 肥 & 䨑 肉炎 & 生 - 肥 & 类肉炎 \\
\hline 12 年 & 11 & 4 & 9 & 6 \\
\hline 13 年 & 16 & 2 & 13 & 2 \\
\hline 14 年 & 22 & 6 & 14 & 2 \\
\hline
\end{tabular}

步理的肥大：赫肉炎 $=85: 20(25 \%)$

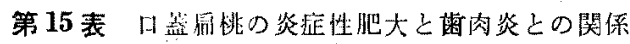

\begin{tabular}{|c|c|c|c|c|}
\hline 性，別 & \multicolumn{2}{|c|}{9} & \multicolumn{2}{|c|}{ tx } \\
\hline 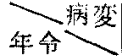 & 炎 - 能 & 歯肉炎 & 炎 - 肥 & 歯肉 炎 \\
\hline 12 年 & 30 & 10 & 24 & 16 \\
\hline 13 年 & 35 & 20 & 31 & 13 \\
\hline 14 年 & 61 & 36 & 55 & 31 \\
\hline
\end{tabular}

炎症性肥大：菌肉炎 $=234: 126(54 \%)$

從つて，生理的つ口蓋扁桃鿱大者に比して资应性肥大 涽には，雨肉炎が約 2 倍强の割合に多い，両者間には明 らかに有意の差が認められた。

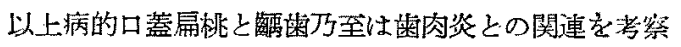

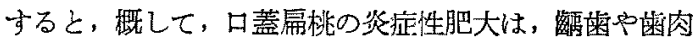
炎と樑い関連を有する事が観察された。このような関係 の発現は，解部学的にも，病理学的にもまたは絊菌学们 にむ想像はできるが，殊に，解剖学的のリンパの洗路に

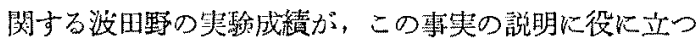

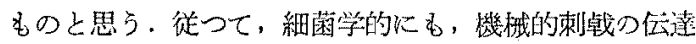

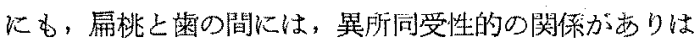
せ收かと相像された、そこで，この想定を重付けるだ

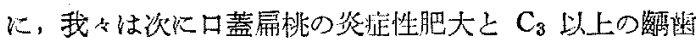
について梌討して見た。

すなわち，それらの同側性について検訫した結果は，
炎唗性肥大の方る 厥桃所有者 234 名中僅か、14名（6\% 弱）にだけ鹤雨の存在する側の口蓋扁桃に高度の苪变が 認められたに過ぎなかつた（第 16 表）.

第 16 表口蓝扁桃の病変之醋雪との関係 （特に同側性について）

\begin{tabular}{cc|c|c}
\hline 年 & 命 & 男 & 女 \\
\hline \hline 12 & 年 & $2 / 30$ & $1 / 24$ \\
13 & 年 & $2 / 35$ & $1 / 31$ \\
14 & 年 & $4 / 61$ & $4 / 55$
\end{tabular}

同湖性一致例数 $/$ 炎症性肥大例数 $=14 / 234(6 \%)$

この予期に反した成績から判断すれば，畨と日蓋扁桃 間のリンパの流路は，㬰地臨床上の慧義は余り瀜くは評 洒できないものと思われる。

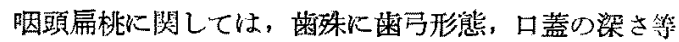
に閶し数多の研究がなされている事は既述の通りである が，我ふは，さらに，口蓋扁桃二次定性肥大がある場会

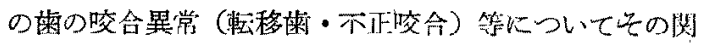
惪程度を比較研究して見た。

その結果，第 17 表のよ5に234名中 15 名の逶の晈会 暴常者加あり, 全体の7\%に相当している.したがつて,

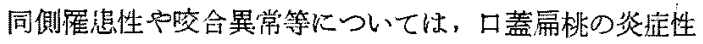
肥大と整上以殆んど関連をるたない事が分つた。なお咬 合異常については,被検者䏺が米の交換期にあるため,永 久迷列の暴常についてのみ採択したるのであつて，一般

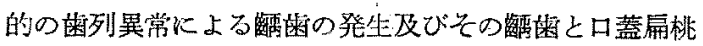
間の関連については，成人に和ける今後に残された閤題 である。

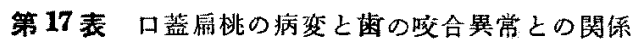
（枟移圈・不正喛合）

\begin{tabular}{|c|c|c|c|}
\hline 年 令 & & ·男 & 女 \\
\hline 12 & 年 & $1 / 30$ & $1 / 24$ \\
\hline 13 & 年 & $3 / 35$ & $2 / 31$ \\
\hline 14 & 年 & $5 / 60$ & $2 / 55$ \\
\hline
\end{tabular}

㗪合舆常 $/$ 炎・肥大例数 $=15 / 234(7 \%)$

最後に観察総人只につき検查結果を総括して，口蓋扁

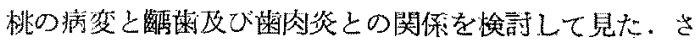
きに, 口蓋扁桃の炎症性肥大の場合々鹤蝕度 $\mathrm{C}_{1}, \mathrm{C}_{2}$ 程

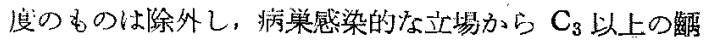

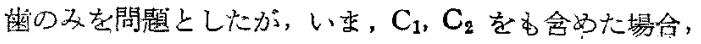

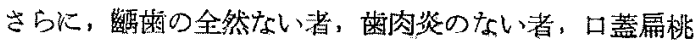


第 18 表 検查絬果の総画

\begin{tabular}{|c|c|c|c|c|c|c|c|}
\hline \multirow{2}{*}{ 年令・性 } & \multirow{2}{*}{ 口蓋 } & & 㓻 & \multicolumn{2}{|r|}{ 雪 } & \multicolumn{2}{|c|}{ 菌肉炎 } \\
\hline & & & $\mathrm{C}_{3} \mid \mathrm{c}$ & ${ }_{1} C_{3}$ & $(-)$ & $(t)$ & $(-)$ \\
\hline \multirow{3}{*}{ 12年 8} & 焱应性肥大 & 30 & 20 & 7 & 3 & 10 & 20 \\
\hline & 生理的肥大 & 11 & 6 & 3 & 2 & 4 & 7 \\
\hline & 所見なし & 84 & 34 & 39 & 11 & 7 & 77 \\
\hline \multirow{3}{*}{ 12年？ } & 炎症性肥大 & 24 & 15 & 8 & 1 & 16 & 8 \\
\hline & 生理的肥大 & 9 & 3 & 6 & 0 & 6 & 3 \\
\hline & 所見なし & 76 & 23 & 37 & 16 & 5 & 71 \\
\hline \multirow{3}{*}{ 13年 } & 炎症性肥大 & 35 & 19 & 14 & 2 & 20 & 15 \\
\hline & 生理的肥大 & 16 & 5 & 7 & 4 & 2 & 14 \\
\hline & 所見なし & 124 & 37 & 64 & 23 & 7 & 117 \\
\hline \multirow{3}{*}{ 13作 9} & 资症栍肥人 & 31 & 22 & 8 & 1 & 13 & 18 \\
\hline & 生䭪的肥大 & 13 & 8 & 5 & 0 & 2 & 11 \\
\hline & 所見なし & 105 & 17 & 92 & 16 & 4 & 101 \\
\hline \multirow{3}{*}{ 14年 8} & 资症性肥大 & 61 & 28 & 27 & 4 & 36 & 25 \\
\hline & 生理的肥大 & 22 & 4 & 9 & 9 & 6 & 16 \\
\hline & 所見なし & 124 & 15 & 83 & 26 & 8 & 116 \\
\hline \multirow{3}{*}{ 14年早 } & 炎应栍肥大 & 53 & 31 & 17 & 4 & 31 & 22 \\
\hline & 生理的肥大 & 14 & 4 & 10 & $0^{\prime}$ & 2 & 12 \\
\hline & 所見なし & 131 & 22 & 76 & 33 & 9 & 122 \\
\hline & 部 & 963 & & 963 & & & 963 \\
\hline
\end{tabular}

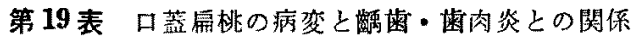
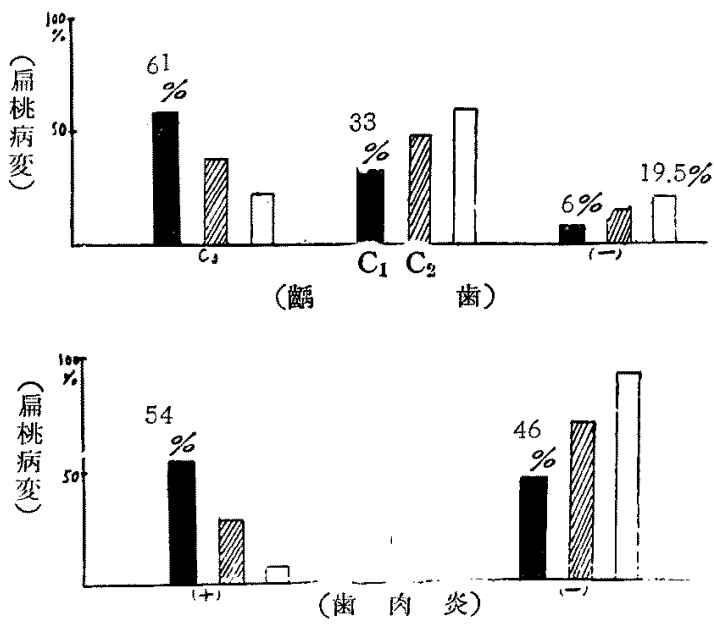

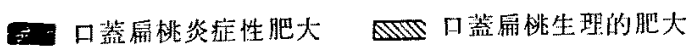
口羕扇桃红所見なきもの

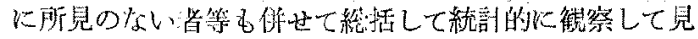
ると, 次の上らな成瓶が出た。

各年命別，恩女別の 例数は第 18 表の通りである。こ

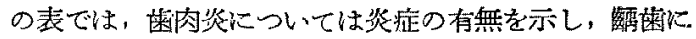
ついては同一口腔内で $\mathrm{C}_{3}$ と $\mathrm{C}_{1} \mathrm{C}_{2}$ の諳とに区別した。.

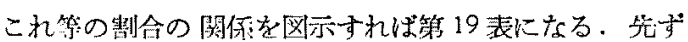

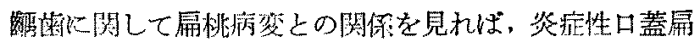

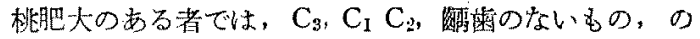
順艺れぞれ61\%，33\%，6\%の㫪合で関保がある事儿

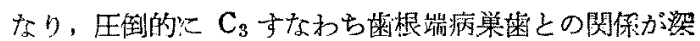

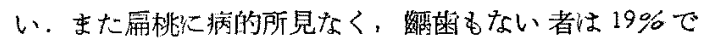

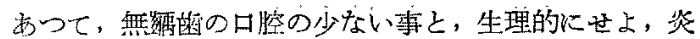

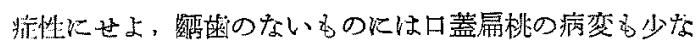
い事が判明した。

雨肉病变との関連ては，画肉绝症を有する者の 54 \%k屏桃の炎症性病変があり，蒾肉飞病的所見のない

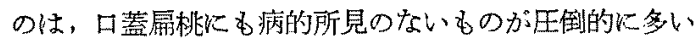
(93\%).これらの点占り，料肉炎のない群の $46 \%$ に扁 桃の炎症性肥大が見られてはいるが，この病的肥大は圈 肉の病変とは直接の関保がないるのと見做せるのではな いであろらか，な招，粕肉病变として畨槽膿漏症等も一 応考慮す心゙ものとは考学るが，我々の倹査では年令的 に該㸻患は全く見当らなかつた。

\section{第 3 編 考按並びに結論}

我々は，口蓋扁桃と歯との病態生理学的関運を研究す るため，満12于上り满14于迄の生徒 963 名につい

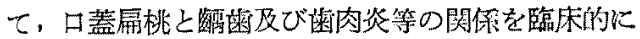
検萦した。

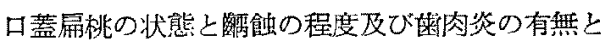
の関保は第 2 編に述べた通りである.12おより14才 迄上年令制限を行つた理由は，与でに，交献的考察 の項で述べたよう，口蓋肁桃が生理的か病的か問 题となるのは，扁桃が生理的菜縮を起す以前の時期 であるからである。我々は管ず口蓋扁桃を踾床的に 生理的肥大と炎症性肥大とに分け，それ，各稳の条

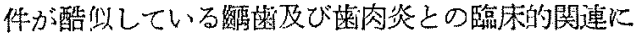
就いて检查を行なつだ。

その結果次のような結苚化達した。

1) 口蓋需桃は，Mackenzie の分類儿上る第 1 度

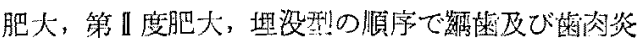
と阅㜕がある。

2）口蓋扁桃の炎症（肥大及び埋没型を含む）は，

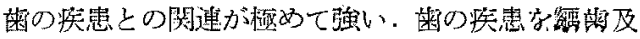


び断肉炎に区分して，その個タの疾患について口蓋扁桃 の炎症との関保を検討して見ると, 口蓋扁桃の炎症性肥

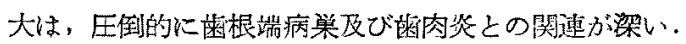
この束整は解剖学的にも明らかである。

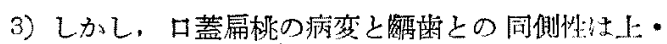

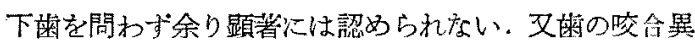
常との関係も明らかではない。

4）これらの矤艎炕関しては，臨床上の境域矣患であ るから，それそれれの立場から，耳鼠科医及び料科医の協 力が望まれる， 口蓋扁桃の炎症性病変の治燎江当つて

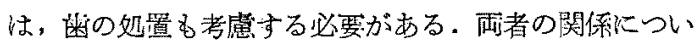
てはさらに今後の研究を要する点が残されれている。

\section{弘用及び参考文献}

1) Dorendorf: Internat. Mshr. f. Anat. u. Phys. Bd. 17, 1900. 2) Most: Arch. Anat. f. u. Phys., Anat. Abteil. 1901. 3) Schweitzer: Arch. f. Mikr. Anat. u. Entwickel-geschichite. Bd. 69, 1907. 4) Henke: Arch. f. Laryn. Bd. 28, 1913.5 5) 永 井：北越医学会誌， 49, 11，1934. 6) Magnus: Deutsche Mschr. f. Zahnheilk. 1922. 7) 西塚：大日蒾 会誌，26，1933．8）波田野：日不學，42，6，1936。

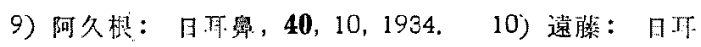
鼻，40，10，1934，11）山崎(春)：医学上生物学,

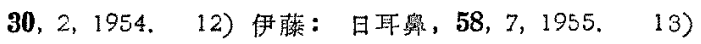

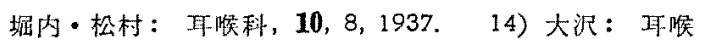
科, 9, 7, 1936. 15) 伊吹：耳喉科, 9, 7, 1936. 16)

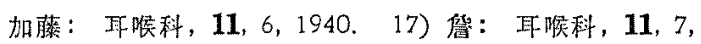

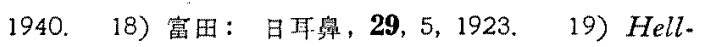
mann: Beitr. z. Patho-anato. u. z. Allg. Patho. 68. 20)細谷・山本：届桃腺病学, 金原望店, 1932, 21)
Levinstein: Arch. f. Laryng-usw. Bd. 22, 1909.

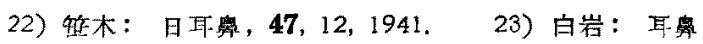

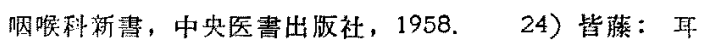

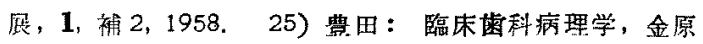

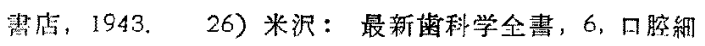
菊学, 永未露店, 1949,27) 竹内：日本歯利医皈会

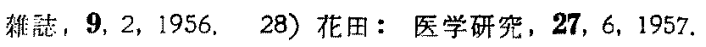
29) 作藤（重）：耳㮢科，25, 12, 1953.30 ) 光本： 治療及び処方，24，10，1943.31）猪：耳㮢科，25， 12，1953，32）猿渡：日本耳鼻咽喉科学全書，6（2）， 克詖堂，1934. 33）山本（常）：耳堠科，29，7，1954. 34) 佐藤 (1)：耳喉科, 29, 9, 1954.35$)$ 正木：日

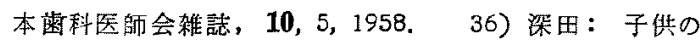

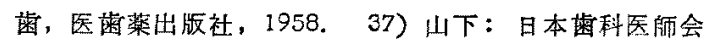

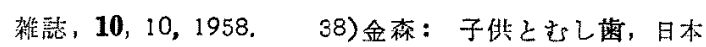
找能教育図書社, 1946. 39) 抨根：菌学, 41.1 2,

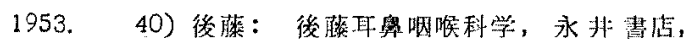
1951.

搁筆するに当り御愁第な御指導と御校閲とを

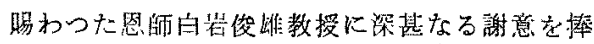
げる。また取材にあたり種々御便宜を賜わつた

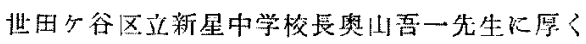
御礼审上げる。

本論交の要旨は，昭和 33 年 12 月日本式桼咽 喉科学会関東地方会籍 357 回例会及び昭和 33 年 11 月第 66 回東京医科大学医学会総会比括い てそれ旮れ口演発表した。

（原搞到着三昭和 35.2 .22 日） 